\title{
MAGIC AND PLAGUE IN THE OTTOMAN EMPIRE
}

\section{INTRODUCTION}

Another key aspect to understanding Ottoman notions of plague is that treatise writers until Hamdan's 1838 reform frequently referred to magic or esoteric knowledge in a variety of forms to call on or channel the supernatural, or forces unintelligible to human logic, to alleviate human suffering or avoid death. Certainly, writers during the sixteenth and early seventeenth centuries, such as Bitlisi and Taşköprüzade, cited the time-worn formulas of Ahmad al-Buni (d. 1225) and other believers in the ritual use of Quranic verses, words, prayers and talismans in an attempt to secure divine intervention to save one from the disease. ${ }^{1}$ Ahmed Efendi similarly advocated astral magic to ward off plague in the Ottoman court during the late seventeenth century. ${ }^{2}$

Recent historians of science and medicine, beginning with Frances Yates, have successfully demonstrated that magic was also an elastic, but continuing element in European history during the thirteenth to the eighteenth centuries. ${ }^{3}$ In the English case, for example, treatise writers on magic, including such sub-areas as cabala, a form of mystical understanding of the world based on Hebrew and Biblical texts, names and prayers, as well as astrology, divinations, conjuring, necromancy and alchemy, were profoundly affected by human tragedies (for example, London's great plague of 1665, the 1666 London fire, the English Civil War) and the social and ideological consequences of Protestant confessionalism. Similarly, the formation of an early modern English body politic, based in part on an emerging sea-borne merchant economy and a print culture reflective of those interests, also brought about significant change in the way magic was formulated and marketed by scholastics to their home audiences. Magical ideas prominent 
during this time included the cabala and talismanic astral understanding of elements and symbols to affect celestial and earthly elements. Cabala and talismanic enthusiasts often promoted a humanistic reassessment of religious texts. These enthusiasts often deconstructed classical conceptions of the world as an earthcentred Ptolemaic universe and as a global Galenic balance of the humors and the elements. One can also see a profound thread of both cabalistic and talismanic understandings of the plague in sixteenth- to eighteenth-century English plague literature, a still largely unexamined area in the historical literature. ${ }^{4}$

This chapter will suggest that, by referencing the English case, one can find comparable Ottoman cabalistic and astrological understandings of plague throughout the early modern era. Arguably, Ottoman writers, such as Ahmed Efendi or the above-mentioned sixteenth-century Ottoman writers, had a world view that related in many ways to their English and European contemporaries. The question, however, is the extent to which these Ottoman writers' socioeconomic, cultural and geopolitical contexts, as reflected in their changing professions, audiences and markets, differentiated the function and content of their work from their English counterparts. A detailed analysis of Ottoman and English treatise literature as they relate to cabalistic and the talismanic/ astrological understandings of plague is necessary to answer this question.

\section{CABALISTIC UNDERSTANDINGS}

\section{The Ottomans}

The sixteenth-century Ottoman treatises, such as those of Taşköprüzade and Bitlisi, use the 'knowledge of letters' (ilmi-i huruf) - a mystical understanding of the Quran, the names of God and prayers, through numbers, signs, symbols, elemental and astrological values attributed to the combination of the twentyeight letters of the Arabic alphabet - to offer the reader a cure for plague. These formulas are, in all likelihood, traceable as far back as the eleventh-century work of the Islamic philosopher Ghazali. ${ }^{5}$ Remarkably, Ghazali's, Taşköprüzade's and Bitlisi's work parallels the Jewish cabala, which developed alongside its Islamic contemporary not only in late medieval Andalusia, but in the succeeding centuries throughout the Mediterranean. Taşköprüzade, for instance, noted that he acquired a number of his formulas from Sephardic Jewish refugees to the Ottoman Empire after the Reconquista in 1492, who, allegedly after converting to Islam, passed on their knowledge to him. ${ }^{6}$

As in cabala, Ottoman practitioners of the knowledge of letters believed that they drew their energy from the intermediate plane of existence (berza) between the earthly and heavenly worlds. Humans, as a microcosm of the universe, were 
able to access all three of these worlds: the earthly in life; the heavenly in death; and the intermediate in one's dreams or imagination. Humans were especially vulnerable to the creatures of the intermediate plane: namely, angels, Satan and, most frequently, spirits, or jinn. Jinn were the most directly responsible for inflicting a human victim with the plague by stinging him with a spear or arrow. (Plague treatise writers most often used the term taun for 'plague', as another form of its three-letter Arabic root ( $t a$ 'n), which is translated as 'spear' or 'arrow'.) Indirectly, Satan himself would lead the jinn to plague the people, as Bitlisi argues was the case during Muhammad's day when the plague left Medina and devastated the nearby town of Cahka. Azrail, the angel of death, took the soul of each victim from his or her body when and if the plague victim died.

The treatises offer an arsenal of names (esma), letters (huruf) and numbers (ebced) that one can use to get rid of the jinn when it appears. Often the prayers would cite one of the ninety-nine names of God, such as the Believer (Mumin), the Nearest (Karib), the Purest (Safi), the Venerator (Receb), the Strongest (Kavi), the Mighty (Muktedi), the Everlasting (Baki), the Destroyer (Helak) and the Universal Guardian (Rakib). Very frequently, the author would ask the user to repeat the name, or a similar religious word, a distinct number of times. ${ }^{7}$ For instance, Taşköprüzade directed that:

Reading the name 'the Everlasting' 136 times every day during a plague will save you from the attack of the jinn of a taun. Reading other names such as Islam 371 times will save oneself from taun. This prayer is so powerful that the person who says it will not be harmed even if they step on a scorpion. ${ }^{8}$

The number of times a name should be repeated could often refer to a three- or four-digit alphabetical number code, which only the initiate would have access to, the letters most often forming the three- or four-letter root of yet another name of God.

Many of the prayers would refer to these names in order to call on a celestial power. For example, Taşköprüzade stated that:

Putting the name 'the Mighty' at the end of a Quran will save you from plague. This will effect the harvest moon in the East, which is connected to the planet Jupiter.9

Sa'deddin Süleyman bin Muhammed Emin Müstakimzade, a late eighteenthcentury chronicler, gave similar prescriptions:

In the first night of a lunar month (gure), one should mention a name 'the Everlasting' 341 times and touch his body with his hand to get rid of the hidden 
disease [plague] ... One can write also inscribe the name 'the Purest' on a pumpkin leaf, and put it into violet oil. Hang it on a tube (sise) exposed to the Sun. The person should memorize the name 391 times per day. The oil should be diffused and used like a lotion to protect oneself against plague. ${ }^{10}$

Some of the texts even cross into the sphere of magic which combined cabalistic and talismanic elements. Taşköprüzade called for the writing of God's name on to a person's forehead, the place according to astral magicians where a person's celestial fate would be inscribed. ${ }^{11}$ Müstakimzade stated that:

The name of God 'Universal Guardian' (Rakib) should be written on to a blank sheet and place under a rock seal or should be written on a miskal of silver in order to ward off plague during one's life time. One can write the following on to a piece of paper (Arabic letters: Elif, Lam, Re, Mim, Kaf, Kaf, Ye, Te, Be, Ded, $R e .{ }^{12}$

The rock seal and sheet of silver were important as they connected the name to a terrestrial element.

There are also a number of other passages pointing out the intermediary world of dreams and fears. Taşköprüzade mentions that one cure was revealed to a fifteenth-century Arabic practitioner while asleep:

A disciple of Seyyid Ali-Hamdani saw Hamza in his dreams. Hamza gave him a prayer to expel plague and added that if a person's son is struck by plague, a certain prayer should be written on his fingernails depending on the location of the plague boil. If the boil is on the right side of the body, the prayer should be written on the left hand finger nails and vice versa. ${ }^{13}$

This prayer writing apparently hoped to restore the individual's mystical humoral balance. Another of Taşköprüzade's stories directly relates to the fear of plague and how it could open the gate to the plague-carrying genies (jinns) from the intermediary world:

During a plague in Kasgar, students saw shadows on the wall [of plague-carrying jinns]. They got scared because the creatures had arrows $\left(t a^{\prime} n\right)$ in their hands. The students were ordered to show paper with certain words to counter them. Those who had the paper were saved but those who did not perished. ${ }^{14}$

Despite the formulaic use of names, numbers and rituals to magically cure plague, the Ottoman plague treatise writers also emphasised that ultimately it 
was God who was responsible for turning the disease. Taşköprüzade reflected this tendency in the following prayer:

We ask You to protect us from Your deep sorrow ... O You who have complete power and total control, O You who have hidden kindness, save us from what we are afraid of. The name of God is the best name. He is the God of the earth and the sky. With the name of God nothing will hurt us, neither on earth nor in the sky. And He listens to us and knows everything ... In the names of God, the AllCompassionate and All-Merciful, I am asking You. O God, O Believer (Mumin), O Protector (Muheymen), O Dear (Aziz), O All-Compelling (Cebbar), please rid us of plague ... O God, You are All-Capable (Muktedir) and I am the result of that. You are the owner and I belong to You. You are strong and I am weak. You are rich and I am poor. There is no God but You. Everything will disappear except your kind face ... By Your names, Your hidden kindness ... [and] the number of Your words, please [give] us . . . a remedy. ${ }^{15}$

Here, one gains the sense that reading God's names, and comprehending their mystical, numerical, spiritual meanings would ultimately lead to union with the divine: 'Everything will disappear except Your kind face'. This would imply ascent into heaven, the celestial world. At the same time, however, Taşköprüzade was pleading to God for mercy from people's pain and suffering on earth: 'You are the source of recovery . . please [give] us . . . a remedy'. ${ }^{16}$

The treatise made similar commentaries with regard to the Quranic verses they use in their ritual prayers. The most frequent set of verses to be cited in plague prayers, 'The Opening' (Al-Fatihah), the opening lines of the Quran, touches directly upon this theme of God as the remedy for human suffering:

In the name of God, the Most Gracious, Most Merciful: Praise be to God, the Cherisher and Sustainer of the Worlds. The Most Gracious, Most Merciful. Master of the Day of Judgement. Thee do we worship, and Thine aid we seek. ${ }^{17}$

Another frequently cited verse is from 'The Throne Verse' (Ayat al-Kursi), which states in part: 'His are all things in the heavens and on earth; who is there that can intercede in His presence except as He permitteth?' One also finds the Quran's promise that: 'If God touches thee with affliction, none can remove it but $\mathrm{He}$; and if He touches you with happiness, He hath power over all things. ${ }^{18}$

The Ottoman plague treatises best illustrate such statements of dependence on God's grace coupled with the possibility of individual action through the use of the magical knowledge of letters in two specific prayers. The first, attributed to the great Sufi mystic Ghazali (d. 1111), but actually penned in the sixteenth 
century, is in fact part of a circular talisman of letters and alphabetical numbers that was intended for the beneficiary to wear around his or her neck. The prayer that was necessary to activate the talisman reads:

To You, my God, I extended my palms in every hardship and I received Your grace from every direction. I do not hope from You anything that You are not part of. If I have gravely sinned, it is not hidden from You. You were kind in the past. You are capable of protection in every situation and from every consequence. ${ }^{19}$

The above statement is similar to the earlier prayers in that it calls for divine intervention to cure the disease. One does not find, however, any specific reference to the jinn, a genie or evil spirit that caused the calamity. Instead, the author raises the possibility that the prayer is invalid if being cured is not part of God's ultimate plan, such as when the victim is struck by plague as a punishment for his or her sins. Thus, the prayer reflects a sense of humility in that the victim does not know God's ultimate purpose even if armed with a reinvigorated mystical understanding of the divine.

One can see this humility even in the directions the author gives to reproduce the talisman. Those who reproduce it should be ritually clean, and aware of his or her duty of charity to the poor and those afflicted with disease or pain. 'God created every trouble', but it was the writer's duty to attempt to alleviate suffering. ${ }^{20}$ An illustration of the actual circle, with the prayer above it (see Figure 4.1), is useful for considering the talisman's more magical functions.

The nineteen Arabic letters and numbers (including a remarkable number of ones and nines) correspond to a Quranic verse, which only the plague-bearing jinn that came upon the bearer of the talisman would be aware of. The letters also mystically combine into a variety of God's names: potentially far stronger than simply a single name. If the owner did not happen to don the talisman before being struck with the plague, he or she also had the option of drinking an elixir consisting of water poured on the circle. (At least one reader of the text may well have done so given the smudges and watermarks on the original). ${ }^{21}$

The second example is an oft-cited prayer from Taşköprüzade:

The Name of God is the very kind and very great proof. God is the ruler and does whatever He wants to. There is no power or force but by God, the exalted and great. I take refuge in God from Satan the cursed with the name of God the All-Compassionate and All-Merciful. O God I take refuge in You from the spear $(t a ' n)$, the plague (taun), calamities, sudden death, from being lost in worldly affairs and from bad actions $(k a z a) .{ }^{22}$ 


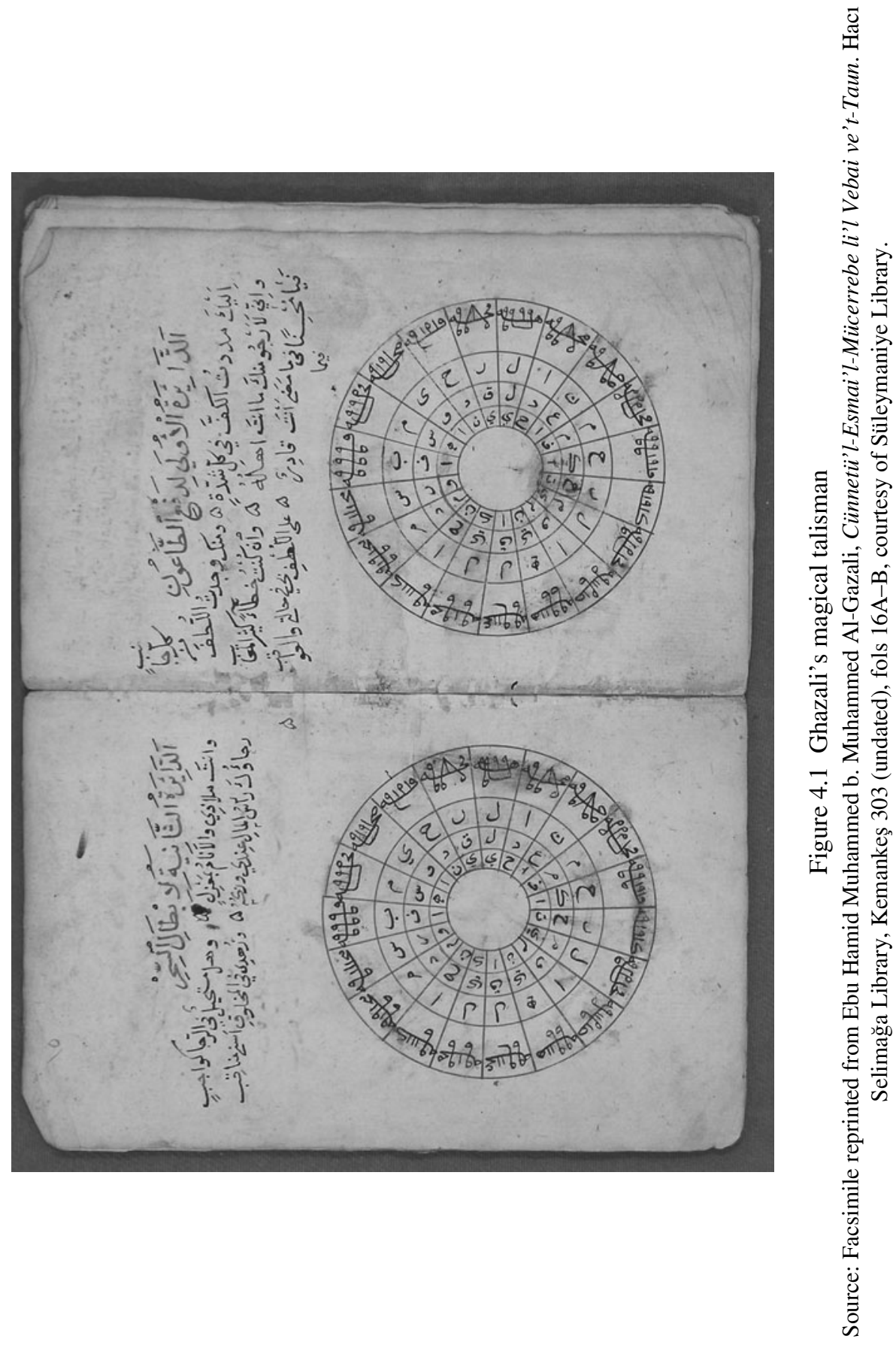


Here Taşköprüzade appears to limit his appeal and use of names directly to God, and connect the plague and the jinn who inflicted it to demonical forces. As in earlier passages, naming God was not mere human-initiated manipulation of celestial powers, but in fact mystical union with God. As formulated, this prayer asks God to either expel plague, or forgive the supplicant for a 'sudden death', 'being lost in worldly affairs' and from sins by welcoming him or her to the afterlife.

This passage is repeated three times in the text, surrounded by the formulas, names and numbers one is supposed to use in conjunction with the prayer, but there are also two significant variations. In one citation - inserted before the last sentence in the above version - it states:

O God, the protector of kinship, drive plague away from us by the right of our Muhammad, the beloved elected one. God commend and salute Muhammad, his family, and friends. ${ }^{23}$

This statement implies that Muhammad, his family and companions may be able to intercede on behalf of the plague victims in a saint-like fashion.

A second variation reveals that Taşköprüzade was willing to speak to issues of fate and human interaction:

$\mathrm{O}$ He who has all the glory and kindness (ikram). In name of God who is known as the great Lord. Every day He is in a different situation. What God wants to happen will happen, and what he does not want to happen will not happen. There is no power except the great exalted God. ${ }^{24}$

Here Taşköprüzade's statement parallels Ghazali's prayer in that he too seems to imply that the individual's fate is up to God's ultimate plans, and perhaps was a form of punishment or trial, rather than a wanton attack by a demon-inspired jinn. Regardless, one must conclude that both Taşköprüzade and the Ghazali texts reflect a great degree of flexibility in terms of spiritual and mystical function to combat the great human suffering and insecurity plague had inflicted upon their societies.

\section{The English}

Remarkably, English spiritual treatises about plague from the fifteenth to the seventeenth centuries strike a number of common themes with their Ottoman contemporaries. This similarity can be seen in prayers against the plague, on saintly intercession and on the use of divine names. Perhaps the most striking 
example of such similarities can be seen in Psalm 91, the single most frequently referenced biblical material in early modern English plague literature:

[1] You who live in the shelter of the Most High who abide in the shadow of the Almighty [2] will say to the LORD, 'my refuge and my fortress; my God, in whom I trust'. [3] For he will deliver you from the snare of the fowler and from the deadly pestilence; [4] He will cover you with his pinions, and under his wings you will find refuge; his faithfulness is a shield and buckler. [5] You will not fear the terror of night, or the arrow that flies by day, [6] or the pestilence that stalks in darkness, or the destruction that wastes at noonday. [7] A thousand may fall at your side, ten thousand at your right hand, but it will not come near you. [8] You will only look with your eyes and see the punishment of the wicked. [9] Because you have made the LORD your refuge, the Most High your dwelling place [10] no evil shall befall you, no scourge come near your tent. [11] For He will command His angels concerning you to guard you in all your ways. [12] On their hands they will bear you up, so that you will not dash your foot against a stone. [13] You will tread on the lion and the adder; the young lion and the serpent you will trample underfoot. [14] Those who love me, I will deliver; I will protect those who know my name. [15] When they call to me, I will answer them; I will be with them in trouble, I will rescue them and honour them. [16] With long life will I satisfy them and show them my salvation. ${ }^{25}$

One sees the invocation of at least four of God's names (that is, the Most High, the Almighty, the Lord and my God). All four of these names had distinct references in their Hebrew original, paralleling the later Muslim use of the ninety-nine names of God. Moreover, the use of these names is highlighted in two formulas: 'He is my refuge and my fortress, my God, in whom I trust' (verse 2) and 'you have made the LORD your refuge' (verse 9). At least two prominent Biblical and Talmudic scholars have claimed that these are in fact formulaic phrases that guaranteed its user divine intervention. ${ }^{26}$ As was seen in the Ottoman prayers, this intervention, 'gaining refuge in God', could mean either union with or deliverance from the plague.

Seemingly, however, the prayer guarantees deliverance from the disease itself. Interestingly, the Psalm, like the Ottoman prayers, makes a direct connection between plague and demonic forces. A number of scholars have traced phrases, such as 'the terror of night', 'the arrow that flies by day', 'the pestilence that stalks in the darkness' and 'the plague that destroys at midday' to specific names of demons from Babylonian and other ancient Middle Eastern mythologies, such as 'Lilth', the witch of the darkness, 'Namroth' and the Babylonian demon of pestilence. The prayer, originally written in the post-Babylonian exile 
period, also apparently has the common Middle Eastern imagery of a winged god. ${ }^{27}$ Nevertheless, the text may also have reduced former gods like Lilth and Namroth to merely evil spirits, something very much akin, perhaps, to the jinn in Islamic sources. Over time, such imagery could also have had a great syncretic value for worshipers. One sees, for instance, that the Psalm mentions the role of angels as guardians in protecting the believer from plague. Thus, the supplicant appealed to one God for intervention, but allowed the possibility for another being, 'a servant of God' to intercede on His behalf.

At least some of the prayer's message (for example, the plague as arrows tied to evil spirits that required the name of God to get rid of it, a special prayer directed at God who alone understood the secret demonical cause of the plague) had a resonance among the spiritualist writers on plague. These included Henry Holland, a Calvinist preacher who wrote a commentary on Psalm 91 in 1593; William Kemp, who wrote a broader account on the causes (spiritual and otherwise) of the Great Plague that struck London in 1665; as well as E. Davies, whose sermon on plague was published shortly after the Marseilles outbreak in $1720 .^{28}$

Other documents promised saintly intercession, such as a 1520 receipt that granted the bearer deliverance from plague in return for the donation of time or monies to the hospital of St Roche in Exeter:

The graces following be granted to all brethren, sisters, benefactors and gooddoers unto the hospital of the blessed confessor St. Roche founded and established within Lyte Exeter. If they do a Pater Noster, Ave Maria and the Crede it is granted them that they shall never be affected nor grieved with the stroke of pestilence. It more plainly appears in his legend how and when Almighty God granted to this petition to the said confessor St. Roche sent by his angel Raphael. ${ }^{29}$

Apparently, the belief that an intermediary of God, such as St Roche, and perhaps the angel Raphael, could save one from plague was common enough in England that it could be used as part of a pious foundation's market strategy.

The prayers to which the document alludes, namely, the Our Father, Hail Mary and the Nicene Creed, bear similar features to the above-cited plague prayers. While the Hail Mary prominently included a request for 'Mary, full of grace' to intercede on the believer's behalf and the Nicene Creed recognised God as the creator of the invisible (for example, spirits), the Our Father praised the name of God (that is, 'hallowed be Thy Name') in order to save the supplicant (that is, 'deliver us from evil'). The Our Father, in conformity with many such prayers, both Christian and Muslim, also implied that human suffering undoubtedly also resulted from sin (that is, 'lead us not into temptation').

One should finally note that such beliefs in the possibilities of divine 
intervention very well may have had a long-lasting symbolic legacy: the red cross, which was used by the English authorities in the mid-seventeenth century as the sign of a household or place struck by plague. The red cross, by no strange coincidence, was also tied to the myth of St Roche. ${ }^{30}$ This patron saint of plague sufferers was born with the symbol of the red cross on his breast, and after a lifetime of service to the sick and needy, was popularly commemorated in England and Scotland in particular. The oft-used phrase 'Lord have mercy' also recalls the common themes of plague prayers, despite the fact that no outward published reference to the saint survived the Protestant-dominated London of 1665. ${ }^{31}$

Yet there were cries throughout the seventeenth century for a reformed understanding of the plague which was highly critical of ritualistic spiritual healing. James Balmford, writing after the plague outbreak in 1625, told his audience that material remedies were much more in order: '[Do] not . . . depend on extraordinary means (miracles and such like) when we may enjoy ordinary [ones].' At best, invoking plague prayers like Psalm 91 would be a vain attempt to understand God's secrets: 'For it is written ... that secret things belong to God and revealed things belong to us.' At worst, using prayers to secure divine intervention would be 'tempting God' in a way similar to that of Satan in tempting Jesus to throw himself down from the top of the Jerusalem Temple knowing that God the Father would be obligated to save him. ${ }^{32}$

Unsurprisingly, there were cries by people like Thomas Hastler, who used similar arguments in 1615 to denounce earlier plague practices as heretical 'papism':

But if it were possible for them to hear such unlawful prayers of men, they would with both hands (as we say) put them from them, and laboured to purge themselves from such flat idolatry, with their song of obedience. Not onto us Lord, not onto us, but to thy name be such honour ascribed.

But our Romish doctors, to maintain their invocations of celestial spirits, do cozen simple people nowadays (as their predecessors did the Christians in the apostles' time) under the pretence of humility, saying that the God of all things was invisible, inaccessible and incomprehensible: and therefore (as Theodoret testifies) they counselled their followers to procure God's favour by the means of angels: like as the heathen idolaters to cover the shame of their neglecting of God ... The very same rag our Romanists had borrowed from them to cover their superstition with that wickedness thereof might not appear. ${ }^{33}$

Here Hastler brands any type of prayer for intercession as akin to demonical witchcraft. Just as using God's name in such a prayer was sacrilege, as the name's honour belonged to God alone, so too calling on any intermediary, angel or saint alike, was heretical nonsense: 
Rome would have us believe that during the time of pestilence we must pray onto none but Saint Sebastian, and his successor, Saint Roche, saints invented to intercede against such a deadly disease: wilfully and directly opposing and contradicting the command and counsel of the Lord of Hosts. ${ }^{34}$

Stories of magic causing plague, rather than curing it, began to gain much more currency:

In the year of Our Lord 1572 when a certain woman of Rezna in Poland was buried near the Church of the Exultation of the Holy Cross, the plague began to rage and spread extremely. ${ }^{35}$

The author of this passage, William Kemp, related another story from Simon Kelwaye in 1593 of ill-fated 'natural magic' as responsible for the troubles of his own times:

When we see young children flock themselves together in companies, and then all will feign some of their company to be dead amongst them, and solemnise the burial in a mournful sort, this is a token which has been well observed in our age to foreshadow great mortality at hand ... And I have heard that one did foretell our late unhappy civil wars, by seeing boys and children make officers, muster and imitate the train bands; saying, when he was in Germany, before the wars did there begin, the children there did the like. ${ }^{36}$

The question here, however, is what Kemp saw as the ultimate cause of the plague outbreak in 1665, and, by inference, the recent English Civil War. Did child play cause the plague or make their countrymen engage in open warfare or was the ultimate explanation to be found in imagination. The issue then would be, if the plague or wars started as a stray thought, would it be tied to the demonridden intermediary world or would it be instead the product of human imagination, a new-fangled microcosmic idea which would make man, not God, the focal point of disease and the universe at large.

Undoubtedly, writers like Henry Holland in 1593 still clung to the idea that demonic spirits caused plague, regardless of whether a ritualistic name-based spell could inflict or cure the disease:

They [the plague-bearing evil spirits] persuade by a marvellous and invisible means, piercing by reason of their airy, thin bodies, the bodies of man when they perceive it not, and so confounding and mingling themselves by means of some imaginations conceived, with the motions of their minds both waking and sleeping. ${ }^{37}$ 
One does not perceive similar sentiments among the plague treatise writers by the time the plague struck London in 1665:

The plague ... is spread by fear and imagination. From the heart proceed the vital spirits, which are its lifeguard, and if they by fear are dissipated, or retire inwards, or leave the outward parts forsaken, which in infectious times are as it were environed and besieged with pestilential air, in comes the plague like a prevailing enemy, and easily enters the gates, scales the walls, and surprises the heart, which like a coward in extremity of danger, is not able to help itself, or make resistance. ${ }^{38}$

The above statement focuses on the concept of vital spirits, an idea originally coined by Aristotle, that a spirit or soul was the organising principle to the human body. What we see here, however, is a fundamental revision of that concept, in human-centred terms. Prior to the seventeenth century, God was ultimately responsible for determining a vital spirit's final cause. Now, we find, similar to Descartes' philosophy on mind and body, that the person could control their own health by controlling their emotions. Thus, if human rationality conquered fear, it could also conquer plague itself. ${ }^{39}$ John Gadbury, an astrologist contemporary of William Kemp, confirmed this when he wrote of plague that:

We find experimentally, that our reason and understanding, and all our noblest faculties, are led captive by our imagination ad libitum; and we are enslaved ignobly, and yet to remain such fools as to indulge our injurer. ${ }^{40}$

Others, like Thomas Brooks, a preacher who wrote a plague treatise shortly before he himself perished in the 1665 outbreak, took a far dimmer view of the human rational ability to overcome nature:

The plague is more immediately from God, than any other sickness or disease; it is the immediate stroke of God. The scribe is more properly said to write than the pen; and he that make and keep the clock is more properly said to make it go and strike than the wheels and poizes that hang upon it: and every workman to effect his work rather than the tools which he used as instruments. So the Lord of Hosts, who is the chief Agent and Mover in all things, and in all actions, may more fitly and properly be said to effect and bring to pass all judgements, yea, all things which are done in the earth, than any inferior or subordinate causes; seeing they are but his tools and instruments, which He rules and guides according to His own will, power, and providence ... Certainly, those are physicians of no value, that cannot look above second causes to the First Cause, they cannot 
look to the wheel within the wheel. The plague is a hidden thing, a secret thing; it is a sickness, a disease, but more immediately comes from God than any other sickness or disease does. ${ }^{41}$

Here Brooks posited that the plague's divine logic simply surpassed the physician's ability to overcome it. A key difference between Brook's vision and that of a number of earlier attributions of plague to a divine cause was not his despairing of divine salvation from death, but his mechanical vision of the God-driven order. ${ }^{42}$ He used this vision, however, not to justify material measures against the disease, but to prove that such measures were indeed hopeless. This begged the question why an all-powerful God would use plague to kill good people:

that some of the best of the Christians should fall by the pestilence, when many of the worst of sinners have their lives for a prey; these are some of those mysterious providences that many times make some of the best Christians to stagger in their judgement; and why so, but because they look upon God's proceedings through a double medium of flesh and spirit; hence it comes to pass all things seemed to run cross, and that God's most just and righteous proceedings, are not so clearly and fully discerned as might otherwise be. The wheels in a watch or in a clock move contrary to one another, some one way, some another, yet all show the skill and intent of the workman, to show the time, or to make the clock to strike: so in this world divine providence is seen to run cross to divine promises; the wicked are spared, and the righteous are taken away; yet in the conclusion all issues in the will, purpose and glory of God. ${ }^{43}$

Again, in contrast to Kemp and Gadbury, ${ }^{44}$ Brooks offers no hope of either spiritual material or human initiative against the disease itself. God's logic was simply beyond mankind's comprehension, leaving the individual with the sole task of pursuing his or her understanding of God's ultimate justice. Curiously enough, Brooks uses cabalistic imagery to illustrate this point:

I have read of a lodestone in Ethiopia, which has two corners, with the one that draws iron to it, with the other it puts the iron from it: so God has two arms, the one of mercy, and the other of judgement; two hands, the one of love, the other of wrath; with the one he draws, with the other he drives; the one strokes, the other strikes: and as he has a right hand of favour, wherewith leads to the saints, so he wants not a left hand of fury, wherewith to dash the wicked to pieces. ${ }^{45}$

This passage once again highlights Brooks' argument that God's power was embodied in material logic. A mere human being could not grasp the physical 
principle behind the logic, but it could understand its spiritual existence. The goal was, thus, to seek mystical union with the divine, with its implicit recognition of the Hebrew cabalistic stages of 'God's two arms': Din, 'judgement' or the arm of 'wrath'; and Hesed, 'mercy' or the arm of 'love'. ${ }^{46}$ In contrast to understandings of the cabala as a multi-stage spiritual bonding in the present world, Brooks saw this pathway to salvation as lying only in death.

Brooks used a second, more talismanic illustration to make the same argument:

Though death, through the pestilence, be to the wicked as the rod in Moses' hand that was turned into a serpent; yet to the godly, death, the pestilence, is like the wand in Elijah's hand, a means to waft them over into a better life. ${ }^{47}$

In his eyes, magic, like science, or even spiritual promises like Psalm 91, was limited to death and a promise of life after death. Nevertheless, it is striking how Brooks identified spiritual equality as yet another theme in this process:

So 'tis here, the noisome pestilence, or the pestilence of grief (as the Hebrew runs in Psalm 91:3) has an equal aptness to cut down one man as well as another, the rich as well as the poor, the honourable as well as the base, the strong as well as the weak, the prince as well as the peasant, the emperor as well as the carter. ${ }^{48}$

This vision of death and the dispatch of the victim to eternal judgement as a great equaliser was matched by the positive vision of social utopia for those who reached heaven:

The promises of God are a Christian's Magna Charta, his chief evidence that he has to show for his preservation, for his protection, for his salvation ... O how highly do men prize their charters and privileges! And how carefully do they keep and lay up the conveyances and assurances of their lands! O how should then saints treasure up those precious promises, which are to them instead of all conveyances and assurances for their preservation, maintenance, deliverance, comfort, and everlasting happiness. ${ }^{49}$

This statement first implies that the quest for greater political and social equality may have also been a hopeless material endeavour. To Brooks, there was no sense in grasping 'charters and privileges' when the saintly plague victim could keep God's promise of eternal life. Oddly, Brooks also noted that such promises include Psalm 91's guarantee of divine deliverance from plague, when his passage infers that this may well simply be an earthly 'charter and privilege'. 
Could it be that Brooks in despair is asking his readers to discard this 'promise' in the hope of ultimate redemption? If so, this would imply a problem with Psalm 91: was it the accurately recorded word of God? Could Brooks possibly have implied that the meaning of the scripture itself also defies human comprehension or that it was mistakenly recorded in the first place? Either interpretation would lead to questions about biblical authority that many Protestants of Brooks' day would certainly have taken issue with as it questioned the then cherished principle of sola scriptura. ${ }^{50}$

It is remarkable to note the pervasive sense of despair and fear in the English spiritual plague literature given the general argument that 'progressive' and 'effective' measures like quarantine and other state-initiated reform had alleviated human tragedy to a much greater extent than when the plague first broke out in 1347-8. One finds instead that both the writers and their audiences reflected the frustrations of their times. The seventeenth century may have allowed for a new mechanical philosophy that increasingly saw the individual and the state as being able to master nature and its calamities, but the reality was that tens of thousands of died of plague despite the quarantines and the Bills of Mortality. A wealth of new medical activity did nothing to stop the continued demand for a spiritual solution..$^{51}$

The effect of confessionalist propaganda and the desire to control and discipline individual spiritual activity had only lessened the ability of the audience to resort to ritualistic prayer and saint worship. This can be seen most clearly not only in Hastler's anti-Catholic polemics, but also in the changing attitudes towards cabalistic prayers like Psalm 91. One can speculate that even in the early sixteenth century the common worshiper still had ready access to churchsupported ritualistic prayers in the hope of saving oneself from plague, perhaps even including chants of God's names to secure divine intervention. But by 1593, with the rise of the Puritan movement and the consolidation of Elizabeth I's Protestant state, popular lay preachers like Henry Holland would avoid interpreting Psalm 91 as a cabalistic formula, even though he would maintain the belief that the prayer - as a reflection of God's will - could still save one from the plague. By 1665, even this deterministic faith in God's grace would give way to others who either despaired of spiritual solutions or turned to the new-found belief that human emotions determined who lived and who died from plague.

Certainly, there are significant comparisons to be made between Ottoman and English cabalistic perceptions. Admittedly, there are definite similarities in approach between the two bodies of narrative accounts. The letter magic, the names of God, ritualistic prayer, the stress on the divine and the possibility of saintly and even human initiated salvation from plague that one found 
in Taşköprüzade, Bitlisi and the Ottoman version of Ghazali's circle found a correspondence in similar patterns in Psalm 91 and the lasting popularity of St Roche. ${ }^{52}$ The differences were not to be found in religious content, but rather the social and economic context of the early modern era. The rapid rise of an overseas merchant-based economy in the booming city of London resulted in fundamental changes in the purpose and audience of the spiritual plague treatise writers. While earlier writers were tied to the relatively limited circles of courts, and literate and religious elites and had a relatively small circulation, the late sixteenth- and early seventeenth-century English writers expanded their message via print to new urban and commercial audiences. ${ }^{53}$ This exposed the writers to state-driven concerns of religious orthodoxy, suppressing religious dissent and, as seen in Brooks, calls for the meek acceptance of one's fate.

The transformation of magical imagery is perhaps the best example of this trend. Whereas magic was practised by religious elites and commoners alike prior to the late sixteenth century, the use of cabalistic chants was increasingly restricted thereafter. Seemingly, the only ones who could use such concepts were those literary and religious elites who applied it ideologically to justify an array of reforms or social disciplinary ideas. Brooks's symbolic use of the Jewish cabala, Moses' and Aaron's magic rod and wands, like that of the divine watchmaker metaphor are clear examples of this trend. His symbols conveyed the message of accepting one's fate and limiting social dissatisfaction in a time of grief and dismay. Such imagery, like the preceding propaganda of religious and social intolerance, was a dark aspect of early modern history that the Ottomans simply did not have to deal with.

\section{ASTROLOGY AND TALISMANIC UNDERSTANDINGS OF PLAGUE}

\section{The Ottomans}

Ahmed Efendi's composition of an treatise on astrology and the plague in the mid- to late seventeenth century provides a great number of insights into changes within astrological practice in the Ottoman Empire during this time and the increasing role of talismanic magic. Earlier texts, such as Bitlisi and Al-Yahudi, acknowledged celestial causes as the reason behind plague, citing Quranic or ancient philosophical texts as their prime authorities. Bitlisi, for example, argued that the Quran states that 'day came into existence with the rising of the sun' and that God created plants and animals in alignment with celestial bodies: 'Every piece of earth is tied to the heavens. The heavens have power over those subordinate to it. ${ }^{54}$ This was perhaps best demonstrated by the continual effect of the sun and moon on tides and the earthly environment: 
Celestial bodies like the sun, the moon and stars can cause putrefication as well as health. For example, if the moon does not cool, then seas and rivers will shrink as a result, and herbs and trees will die from thirst. ${ }^{55}$

Al-Yahudi argued that Plato and Hippocrates had shown that the conjunction of Mars and Saturn was responsible for triggering plague. Al-Yahudi further posited that such celestial movements caused earthquakes, storms and other elemental eruptions that would lead to the creation of plague-bearing miasmas. While Al-Yahudi and Bitlisi prescribed various material measures, and Bitlisi also advocated prayer and enumerating the cabalistic names of God, none of these authors saw any elemental, or talismanic magic that could be used to alleviate this situation. ${ }^{56}$

In contrast, Ahmed Efendi made a fundamentally different argument. He emphasised the importance of mastering the strange magical connection between the elements, individual human beings and the stars beyond to understand, prevent and cure the plague. He claimed that gaining an accurate reading of one's horoscope, including the ascendant sign that a person has at his or her birth, was critical to learning the nature of this connection. An astrologer like him would understand one's 'ascendancy by looking at a person's eyebrows'. Consequently, after looking at the individual's horoscope he could, with knowledge of the secret ore for each ascendant star, cast a mould figure of the individual to ward off plague. The mould figure would be made of a certain metal (for example, copper if the person's ascendant star was Venus or tin if Jupiter) and might bear the secret name of a spirit or shape. If that person had the misfortune to be born under an unlucky star, he could 'turn a bad sign into a good one by using certain intoxicating elements like opium'. Such talismans were compounds of terrestrial and celestial bodies that solved a problem.

Similar talismans could be produced for affecting a city or region; For example, jade was known for causing rain. A brass talisman of a snake was forged and placed at the hippodrome in Istanbul to ward off snakes. Spells were also to be used, either in conjunction with the talismans or independently. Ahmed Efendi related the story of how Caliph Memun used a spell to get rid of all the beetles in Baghdad, and how another used a similar incantation to clear Damascus of its scorpions, mice, snakes and spiders. ${ }^{57}$

Three further aspects of Ahmed Efendi's work needs to be highlighted in particular. First, his work on magic, in contrast to Bitlisi and the Ottoman advocates of the 'knowledge of letters', does not refer to magic's tie to the divine, or even to earlier ancient Greek or medieval Arab scholars. This is notable given the traditional citation in these works to Quranic and/or scholastic sources. Curiously enough, Ahmed Efendi was trained as a Mevlevi shaykh as well as an astrologer, 
and spent considerable time as a religious scholar in Mecca, Medina and Cairo after losing his post as the sultan's chief astrologer. ${ }^{58}$

Secondly, Ahmed Efendi's work reveals strategies that were typical of astrologers of that time. He clearly sought to use his book to regain the coveted post of court astrologer. While he gave a general introduction to his art in order to demonstrate his qualifications for that post - highlighting at least two earlier books he had written on the topic - he did not reveal any specific spells or details that others could use to secure the position instead. ${ }^{59}$

Finally, Ahmed Efendi seemed to be well aware of current trends within astrological practice. Not only did he spend time learning in the scholarly and religious centres of the Mediterranean Islamic world - he wrote his two books in Egypt and in Arabic - but he also hinted at an openness towards other more transregional trends, such as his mention of magic as being related to 'mathematics either unleashed from the power of geometry, or from the science of dynamics as seen in a pendulum' ${ }^{60}$ This could be an allusion to new trends that were popular among seventeenth-century scientific circles in Europe, and perhaps beyond.

The intercultural exchange of ideas was a two-way street, however. Raffael Gaffarel, a Frenchman who wrote a defence of astral magic translated into English in 1653, clarified that much of his inspiration on the use of talismans, spells and celestial powers was based on past and present Islamic practices. For example, Gaffarel claimed that the word 'talisman' was originally an Arabic word, and that some of the great Islamic scholars of medieval times, such as Almansor, Messahala, Zahel and Albohazen, were some of talismanic magic's most influential advocates. In Gaffarel's eyes, the Islamic symbol of the crescent and the Quranic story that the fallen angels Arot and Marot brought the knowledge of talismans with them when they travelled to earth, were other examples of this legacy. ${ }^{61}$ Recent scholars of Islamic history, like T. Fahr, confirm that such influences were essential the revitalisation of talismanic magic by late sixteenthand seventeenth-century intellectuals like Giordano Bruno and Gaffarel. ${ }^{62}$

Yet Gaffarel was undoubtedly aware of more recent talismanic practices in the Middle East. Interestingly, Gaffarel highlighted the use of talismans not only on ships to protect them from bad weather and in fields to insure good crops, but also in imperial cities like the former Byzantine capital of Constantinople. One such story, taken from the late Byzantine historian Doukakis, relates the use of a talisman to ward off insects:

It is also reported, that after that Mahomet the Second had possessed himself of Constantinople, the breaking of the lower jaw of a brazen serpent was the cause of the increasing of serpents in those parts. So true it is, that these talismans have the power to direct many of those calamities that afflict mankind. ${ }^{63}$ 
Gaffarel's story tends to romanticise the Byzantines as somehow in tune with their talismanic, Greek past far more than their Ottoman successors, implying as many humanist scholars did that the transfer of ancient knowledge by Byzantine exiles was critical to the revitalisation of Europe's arts and sciences. One should note that this is in contrast to Ahmed Efendi's version of the story, which implies the Ottomans themselves cast the bronze talisman. ${ }^{64}$

Gaffarel pointed out a second, similar account that relates to the Byzantine talismanic practice against plague:

At Byzantium, which is now Constantinople, there were many of these talismanic figures to be seen: but the fury of war has demolished them all, to the great prejudice of the inhabitants. Sultan Mahumet also caused one of them to be broken to pieces, which was a brazen horse, with a horseman upon him; which is certainly reported to have preserved the city from pestilence, and all contagion of the air: but since that time, this disease has raged so fiercely, as that in the space of four months, Leunclavius, who was present, affirms that there died 150,000 persons: and every year, in the months of July, and August, the like effect. ${ }^{65}$

This version once again reaffirms the idea that the Ottomans, particularly Sultan Mehmed II, failed to continue the valuable Byzantine practice of talismanic magic, to the detriment of Istanbul's population. Unsurprisingly, the account propagates the Byzantine version of the conquest of the city as the fall of a great civilisation to barbarism. The claim that Mehmed II destroyed an equestrian statue is significant given that Muslims detested images as symbols of ancient Greek and Roman greatness in the arts.

Nonetheless, one should also compare this account to that of Evliya Çelebi, the famous mid-seventeenth-century Ottoman traveller, who related yet another version. He claims that it was Mehmed II's son Bayazid II, a pious Muslim, who, during the construction of a series of new mosques in the old Byzantine city centre, tore down an ancient pillar erected by the Byzantines to commemorate the conversion to Christianity of the founder of the city, Emperor Constantine. According to Evliya, Bayazid quickly rebuilt the column after plague suddenly struck the city and killed his son. ${ }^{66}$

While Evliya's tale confirms that Bayazid, like Mehmed II, was initially ignorant of the value of talismans to protect the city from plague, it is significant that Bayazid actually rebuilt the column after learning a painful lesson. ${ }^{67}$ Moreover, Evliya's inference that such talismans were used by the Ottoman rulers in Istanbul is confirmed by the survival of three such talismans in the middle of the hippodrome, the great parade ground of the city in both Ottoman 
and Byzantine times. There one can still find the bronze serpent, a smaller column and an Egyptian obelisk, all three talismanical objects that were dutifully maintained by the Ottomans, as is evident from the walls that they built around them. Constantine's monument, some half a kilometre away, similarly still stands today.

Also striking is Evliya's implication of a possible religious motivation for Bayazid, since Bayazid was known as a far more sincere Muslim than his father. Presumably, initially Bayazid could have torn down the column to symbolise his religion's ultimate conquest of Byzantine Christian civilisation. This part of the story corresponds with the earlier efforts of Byzantine authors and European travellers to build up the myth of Mehmed II as an intolerant barbarian. Some Ottoman chroniclers and Western travellers bolstered this claim, alleging that both Mehmed II and Bayazid II sought to rename the city as 'Islam-bol' or the 'full of Islam' rather than simply 'Istanbul', an Ottoman Turkish translation of 'Constantinople' that remains related to its original place name. ${ }^{68}$ Evliya seemingly revised the myth in favour of a sultan who learned that the talisman's magical powers, and perhaps his own tolerance of his realm's Christian minority, was critical to his empire's survival and prosperity. Could it be that Evliya actually was using this story in a similar way to the alchemists of neighbouring European states who employed metaphors to justify ideas of tolerance in age of confessionalist war? ${ }^{69}$

\section{The English}

Evidence of such imagery is particularly clear in the dedications of the English treatise writers. For example, William Kemp started out with the following commemoration to his patron:

To the King's most excellent Majesty Charles the Second, by the grace of God, King of England, Scotland, France, and Ireland; Defender of the Faith, etc.

Most dread and gracious Sovereign: the glorious sun, who communicates his beams and light, not only to the stars and heavens where he doth reside, but also to the air and water, and the remotest part of the earth, where the lowest shrubs are cherished with his influence, is a fit emblem of your Majesty whose pious care was expressed not only for the nobles and courtiers, that have the honour to be near your person; but also for the Commons and inferior people, that have the happiness to be in your mind, in appointing and accepting the directions of the learned College of London, for the cure of, and preservation from the pestilence. $^{70}$ 
This statement, very much reminiscent of Louis XIV (1638-1715), the 'Sun King' Charles II (1630-85) so very much admired, used the astrological symbol of the sun in the heavens to justify his rule in both earthly and celestial terms. Such symbols were an attempt to displace the earlier idea of divine right, which would imply the monarch's dependence on ecclesiastical authority, in favour of the natural legal notion that the universe, like the earth, was subject to lay rules and rulers. Such ideas appealed to kings and the war-torn populace alike, and helped to set in motion support for 'enlightened absolutist' rule. ${ }^{71}$ There are no similar dedications in Ahmed Efendi's or the later Ottoman plague treatises, which leads me to believe that Evliya's symbolism and Ahmed Efendi's awareness of international trends in literature on astral magic were not due to patronage of ideological images from the court per se.

Another issue that Ottoman practitioners of talismanic magic did not have to deal with was the charge of heresy. Gaffarel's treatise was the only printed work in the English language that I found that attested to the use of talismans against plague, referring to the accomplishments of Paracelsus and Crollius, both controversial authors in the mid-seventeenth century:

Now of late many learned men have rescued from oblivion these figures [talismans]; and Paracelsus did take so much pains herein, as that he made diverse of them; and those of such virtue, as that they preserved those that wore them from the pestilence, as many in Germany have had experience of . . . Those also which Paracelsus calls Zenexton, by a Made Name (it being the custom of this author, to devise new words), are made with exceedingly great art. In one of them there is a scorpion and a serpent figured: and he says it must be made when the sun and the moon enter into the sign of Scorpio. In another you have a great number of little holes, with in an oval. You may see the figures of them, in the chemical works of Crollius. ${ }^{72}$

Gaffarel then went on to note that Crollius faced charges of witchcraft for promoting such work. This pressure against occultist and talismanic magic led Gaffarel into an extended discussion as to why talismans actually confirmed acceptable Christian norms. For instance, he claimed that the art first emerged in ancient Israel. He offered discoveries such as the original Hebrew names for the planets (Jacob's son Gad being the name for the planet Jupiter), Moses' practice of the art and the sight of Hebrew letters in the heavens as proof in this regard. Only later, Gaffarel maintained, did the Egyptians corrupt talismanic magic. ${ }^{73}$ He and other apologists for a Christian hermeticism, or talismanic magic, like Cornelius Agrippa, sought to restore the profession to what it once was. ${ }^{74}$

The English astrologers were far more sceptical of such speculation. As a 
whole they tended to defend their profession as a science as distinct from 'superstition', a category which implied talismanic magic. John Gadbury and William Lilly, two of the most prominent astrologists of the second half of the seventeenth century, wrote almanacs that used such astrological reasonings - minus talismans, spells and other magical components - to predict events from plagues to wars, and the lives of individual monarchs. Recognising the twelve zodiacs and the principles of ascendancy, they always argued their works to be the result of long labour over charts, together with foresight and the most modern knowledge of celestial movements scholars could provide. ${ }^{75}$ Almanacs proved to be among the most popular books of their day, tending to have the highest circulation of any printed book short of the Bible during the seventeenth century. ${ }^{76}$

In fact, Lilly and Gadbury went so far as to maintain that astrology could prove plague's celestial causation of ineffectual miasmas rather than the contagionist argument popular among many physicians, particularly magistrates, members of the Royal Medical Society, and opponents of the Levantine cotton trade. At first, Lilly indirectly criticised such opinion in 1644, when he related how ineffectual the Habsburg College of Physicians were in accepting both a contagionist and an astrological cause for plague in $1599 .{ }^{77}$

Gadbury made the bold argument in the immediate aftermath of 1665 outbreak that the London Bills of Mortality proved that the plague waxed and waned according to the celestial movements of Saturn and Mars. ${ }^{78}$ Oldenburg, chief of the Royal Medical Society, strenuously objected to Gadbury's support for the anti-contagionist camp in his correspondence with others like John Boyle. ${ }^{79}$ John Graunt, whose work was central to the newly developing field of "political arithmetic', also discounted such ideas in press in favour of contagionism. ${ }^{80}$ Gadbury responded at length to a similar critique by a contemporary of Oldenburg and Graunt:

There is another gentleman also, a doctor of physick (which title (fairly obtained) and possession of also, I exceedingly honour) has been pulling at me in print, for my maintaining the negative in the question above propounded. This antagonist is angry in earnest and tells the world that I deserve to be answered by the magistrate, and that there is no way to suppress my opinion, or answer my arguments, but by putting in execution an order published in Queen Elizabeth's days ...

And considering some other passages of his, I perceive that he is not more angry at that my opinion, than at the celestial movers, the stars; whom (he says) many have accused as the authors of plague. I have (I acknowledge) in the book before mentioned, proved the stars to be (Sub Deo) the causes of the pestilence.

But this gentleman (not withstanding his aim, and fruitless pains, to render me ridiculous and the stars (I study) ineffacious;) is not (in the meantime) aware, 
of his own running into an error of far greater magnitude; viz. in his asserting the original of the plague to have been ROTTEN MUTTON eaten in the year before.

Now let any rational man consider whether he comes nearest the truth; I, in asserting the stars; or he, in maintaining a rotten mutton, to be the cause of the pestilence. An epicurean may, and frequently does, ascribe more to his belly than on to those glorious and ever-busied lamps of heaven. I cannot stand here to repeat the arguments I have urged to prove the plague contagious; I must refer the reader, for that, to the book itself.

But if rotten mutton be attended with such fatal effects, why not a plague every year after a rot of sheep which is the consequence of every moist summer? Or, if the plague were truly the effect of rotten mutton; how else then does it hold true, what he asserts elsewhere, in the same discourse that the plague came from the Netherlands, and to them from Smyrna, in a parcel of infected goods? Was there a rotten mutton in Smyrna too?

To conclude: let us suffice at present, that I deny any such a way of infection by goods; and reject romance of his rotten mutton: and (as before) do assert, the stars (Sub Deo) to be the true and essential causes of all plagues. ${ }^{81}$

The jocular yet convincing tone of Gadbury's statement was central to convincing his audience to support the idea that celestial movements, not rotten mutton or imported Ottoman cotton, caused plague. This was likely to coalesce with the other anti-contagionist arguments that emphasised that imported goods - like lamb from the countryside or cotton from abroad - were far more of an economic benefit than a public health hazard. This undoubtedly appealed to Gadbury's mainstay: London's entrepreneurs. Gadbury went so far as to name his political opponents - a doctor pushing Elizabeth I's laws - and use the Bills of Mortality against them $!^{82}$ It should be noted that Elizabeth I and her mercantilist advisers were the first to ban an import (French wine) in order to prevent the plague, much to the chagrin of the very shopkeepers Gadbury to whom would later appeal. ${ }^{83}$

Gadbury's combination of astrology and the Bills of Mortality also seem remarkably similar to the way in which practitioners of the cabalistic, occultist and talismanic arts, such as Marsilio Ficino, Pico della Miranda, Cornelius Agrippa and Giordano Bruno, justified the findings of Galileo. This proved once again that combinations of magic and scientific innovation readily sold to a body politic that sought to justify socioeconomic and geopolitical change. ${ }^{84}$

Moreover, Gadbury's work also illustrates a stark difference between Ottoman and English astrological literature. The English literature was aimed at a broad, politically and commercially active audience. Gadbury, Lilly and Kemp were much more in tune with the politics of state-building movements, which 
would justify absolutist notions of sovereignty, governmental regulation of religious and social affairs, and an emerging commercial economy. Astrological charts and tables that graphically illustrated the rise and fall of monarchs, the capturing of new markets, the founding of colonies and the outbreaks of disease tapped into this dynamic medium. One can almost imagine that Gadbury's pamphlets were as dog-eared as any recent publication in the coffee houses, libraries and homes of London at the time. ${ }^{85}$

Ottoman astrologers were certainly not totally isolated from such developments, as seen in Ahmed Efendi's and Gaffarel's shared talismanic magic, as well as Evliya's symbol of Bayazid's magical unification of the empire. However, Ottoman astrologers like Ahmed Efendi still worked within a court culture where their writings had a much smaller circulation. One should not overlook the fact that I have located only one new astrological tract in Ottoman Turkish on plague during the entire seventeenth century; a trend which contrasts strongly with the wealth of printed English astrological literature on plague during the same era.

While Ahmed Efendi and other Ottoman astrologists undoubtedly had an impact on the sultan and his family, palace intrigues and patronage, they did not play the same public, commercial role as London's treatise writers. Consequently, the Ottoman writers were not subject to the same type of ideological scrutiny as their English counterparts.

Gadbury's exclaimer at the beginning of his argument with the doctor that astrology was the superior cause of plague 'sub deo', or 'outside an act of God', was not there by mere accident. ${ }^{86}$ This exception, like his and his colleagues' avoidance of talismanic elements in his astrological predictions, was a direct result of the confessionalist pressure to root out magical practices outside ideological images and justifications. Talismanic magic, like all cabalistic medicine and saint worship, allowed for a type of individual initiative and economy that the state and religious authorities would not allow in print.

\section{CONCLUSION}

The impact of print culture and the political, religious and commercial developments in London during the late sixteenth and seventeenth centuries help to explain why English and Ottoman plague treatises developed fundamentally different functions during this time. Even by the early sixteenth century, it appears that both the English and Ottomans had similar cabalistic perceptions and practices regarding plague in both courtly circles and on a more popular level. This is indeed a far cry from Dols' still dominant interpretation of the Ottoman's static mystical essentialist conceptions of plague. ${ }^{87}$ Moreover, the religious authorities 
of the time also seemed to have sanctioned such practices. Although the English crown and new Protestant ecclesiastical authorities increasingly pressured such practices, particularly on a popular level, intellectual elites continued to cultivate the cabalistic and hermetic/talismanic arts for a much longer period. Ottoman intellectuals, represented by the likes of Ahmed Efendi and Evliya, likely remained in touch with these same schools of thought.

England's state and commercial formation, religious strife, civil war and natural disasters like the plague and the fire of London, put pressures on astrological and spiritual treatise writers on plague to act as ideological agents. Brooks' use of multilayered divine magical, cabalistic talismanic and even mechanical symbols of utopia in the world beyond; Gadbury's combination of astrology and the bills of mortality; as well as Kemp's dedication to Charles II as the 'Sun King', undoubtedly provided valuable justifications for English authorities overwhelmed by the crisis of 1665: social resignation to death from plague; faith that sciences like astrology would master epidemic disaster; and the belief in the sovereign as the source of earthly and celestial authority.

These works were simply state-encouraged efforts at social and political damage control rather than signs of progress against the ravages of pestilence. Undoubtedly, London's suffering masses were frustrated that the plague devastated the city regardless of the promises that quarantines and other medical regulations could contain the damage. References to natural magic, fear and imagination, as well as a growing disbelief that any preventive measure could alleviate the danger, reveal a sense of despondency to which only those who had suffered the untold horrors of religious and civil war could relate. The Ottomans, who remained outside such state-building movements, mechanical and social disciplinary ideologies, never had to 'spin' their way out of such a public accounting. Similar pressure would come about only towards the end of the eighteenth century, when the Europeans began to threaten the Ottoman social order in the name of a disease they had only imagined themselves to conquer.

\section{NOTES}

1. Bitlisi, Husn ül-veba, fols 17A-25B, 33A, 73A-B; Dols, The Black Death in the Middle East, pp. 3-12, 281-302; Taşköprüzade, Risale fi't-Taun ve'l-Veba, fols 182A-5B, 188A.

2. Ahmed, Risale fi Ilmi Tilsim ve Def'i' 't-Taun.

3. Frances Yates, Giordano Bruno and the Hermetic Tradition, pp. 1-156; Frances Yates, The Occult Philosophy in the Elizabethan Age, pp. 3-4, 18-24, 35-46, 107, 116-24.

4. Balmford, A Short Dialogue concerning the Plague's Infection; Thomas Brooks, A Heavenly Cordial for all those Servants of the Lord that have had the Plague ..., or, Thirteen Divine Maximes, or Conclusions, in Respect of the Pestilence: Which may be as so Many Supports, Comforts and Refreshing Springs, both to the Visited and Preserved 
People of God in this Present Day: Also Ten Arguments to Prove that in Times of Common Calamity the People of God do stand upon the Advantage Ground as to their Outward Preservation and Protection ....: Also Eight Reasons why some of the Precious Servants of the Lord have fallen by the Pestilence in this Day of the Lord's Anger; Thomas Hastler, An Antidote against the Plague. Or Panchrestōn: A Salve for All Sores: which applied and practised, will soone awaken the Lord's Mercy, and suddenly cause the Storms of his Iust Judgements to vanish away. Delivered in a Sermon, preached within the Cathedrall Church of Saint Paules, London; Henry Holland, Spirituall Preseruatiues against the Pestilence: Or a Treatise containing Sundrie Questions: Both Concerning the Causes of the Pestilence, (Where is Shewed, that the Plague is a Mixt Euill of Knowne and Secret Causes, and therefore so Hardly Healed by Naturall Curatiues only) and the Most Pretious Preseruatiues against the Same and Many Other Euils. Chiefely Collected out of the 91 Psalme; William Kemp, A Brief Treatise of the Nature, Causes, Signes, Preservation from, and Cure of the Pestilence.

5. Al-Ghazali, Ebu Hamid Muhammed b. Muhammed, Cünnetü'l-Esmai'l-Mücerrebe li'l Vebai Ve't-Taun, fols 4A-8A, 16A-18B.

6. Taşköprüzade, Risale fi't-Taun ve'l-Veba, fol. 188A.

7. Bitlisi, Hısn ül-veba fols 17A-25A, 33A, 73A-B; Taşköprüzade, Risale fi't-Taun $v e ' l-V e b a$, fol. 185B.

8. Taşköprüzade, Risale fi't-Taun ve'l-Veba, fols 182A-185B.

9. Taşköprüzade, Risale fi't-Taun ve'l-Veba, fol. 183B.

10. Müstakimzade, Cihazü'l-Macun fi'l-Halas Mine't-Taun, fol. 46B.

11. Taşköprüzade, Risale fi't-Taun ve'l-Veba, fol. 183A.

12. Müstakimzade, Cihazü'l-Macun fi'l-Halas Mine't-Taun, fol. 46A.

13. Taşköprüzade, Risale fi't-Taun ve'l-Veba, fol. 191B.

14. Taşköprüzade, Risale fi't-Taun ve'l-Veba, fol. 188B.

15. Taşköprüzade, Risale fi't-Taun ve'l-Veba, fols 184A-186B. I wish to thank Mohamed Ben Yahia for so kindly translating this and the following of Taşköprüzade's plague prayers in this chapter from Arabic to English.

16. Taşköprüzade, Risale fi't-Taun ve'l-Veba, fol. 187A.

17. Yusuf Ali Abdullah, The Meaning of the Holy Quran, pp. 14-15.

18. Abdullah, The Meaning of the Holy Quran, pp. 105, 247.

19. Al-Ghazali, Cünnetü'l-Esmai'l-Mücerrebe li'l Vebai Ve't-Taun, fol. 16 A.

20. Al-Ghazali, Cünnetü'l-Esmai'l-Mücerrebe li'l Vebai Ve't-Taun, fols 7A-B, 13A-B.

21. Al-Ghazali, Cünnetü'l-Esmai'l-Mücerrebe li'l Vebai Ve't-Taun, fol. 16A.

22. Taşköprüzade, Risale fi't-Taun ve'l-Veba, fols 187A, 188A.

23. Taşköprüzade, Risale fi't-Taun ve'l-Veba, fol. 187B.

24. Taşköprüzade, Risale fi't-Taun ve'l-Veba, fol. 188A.

25. Bruce Metzger et al., The New Oxford Annotated Bible with the Apocrypha: An Ecumenical Study Bible Completely Revised and Enlarged, pp. 753-4.

26. Walter Russell Bowie et al., The Interpreter's Bible, vol. 4, pp. 493-7; J. J. Stewart Perowne, The Book of the Psalms: A New Translation with the Introductions and Notes Explanatory and Critical, vol. 2, pp. 493-6.

27. A. A. Anderson, The Book of Psalms, vol. 2, pp. 655-60; Othmar Keel, The Symbolism of the Biblical World, in Ancient Near Eastern Iconography, and the Book of Psalms, pp. 82-7, 97, 136, 180-1, 190-1, 223-5, 352-3.

28. E. Davies, A Sermon Preach'd on Friday Decemb. 16th 1720 Being the Day of Publick 
Fasting and Humiliation for the Averting God's Judgments, particularly the Plague, pp. 4, 9-10; Holland, Spirituall Preseruatiues against the Pestilence, pp. 15-19, 34; Kemp, A Brief Treatise pp. 7, 10.

29. Anonymous, The Graces Folowying be Graunted . . 1520.

30. Anonymous, The Mourning Cross, or Lord Have Mercy upon us . . . .

31. J. Campbell, 'Saint Roche', New Catholic Encyclopedia, vol. 12, pp. 540-1; Dols, The Black Death in the Middle East, p. 137, fn. 63.

32. Balmford, A Short Dialogue concerning the Plague's Infection, pp. 33, 60-2.

33. Hastler, An Antidote against the Plague, pp. 31-2, emphasis in original.

34. Hastler, An Antidote against the Plague, p. 21.

35. Kemp, A Brief Treatise, p. 9.

36. Kemp, A Brief Treatise, p. 28.

37. Holland, Spirituall Preseruatiues against the Pestilence, p. 31.

38. Kemp, A Brief Treatise, p. 22.

39. Lex Newman, 'Epistemology of René Descartes', Stanford Encyclopedia of Philosophy (online edition).

40. John Gadbury, London's Deliverance Predicted in a Short Discourse Shewing the Cause of Plagues in General, and the Probable Time (God Not Contradicting the Course of Second Causes) When the Present Pest May Abate, \&c, p. 27.

41. Brooks, A Heavenly Cordial, pp. 2-3, emphasis in original.

42. Davies, A Sermon Preach'd on Friday Decemb. 16th 1720, pp. 9-10.

43. Brooks, A Heavenly Cordial, pp. 61-2, emphasis in original.

44. Gadbury, London's Deliverance, p. 27; Kemp, A Brief Treatise, pp. 7, 10, 28.

45. Brooks, A Heavenly Cordial, pp. 74-5.

46. Danniel Matt, The Essential Kabbalah: The Heart of Jewish Mysticism, pp. 8-9.

47. Brooks, A Heavenly Cordial, p. 70.

48. Brooks, A Heavenly Cordial, p. 5.

49. Brooks, A Heavenly Cordial, pp. 19-20.

50. John Merriman, A History of Modern Europe: From Renaissance to Present, p. 132.

51. A. Lloyd Moote and Dorothy C. Moote, The Great Plague: The Story of London's Most Deadly Year, pp. 183-90.

52. Anonymous, Graces.

53. Elizabeth L. Eisenstein, The Printing Revolution in Early Modern Europe, pp. 3-91.

54. Bitlisi, Husn ül-veba, fol. 29A.

55. Bitlisi, Hisn ül-veba, fols 70A-B.

56. Al-Yahudi, Micennetü't-Ta'un ve'l-Veba, fols 1A-30A; Bitlisi, Hisn ül-veba, fols 2A-79B.

57. Ahmed, Risale fi İmi Tilsim ve Def'i' 't-Taun, fols 85A-86A, 87A-B, 88B-90A, 91A; Al-Yahudi, Micennetü't-Ta'un ve'l-Veba, fols 82B-83A.

58. Mehmed Süreyyā, Sicill-i Osmanī, İstanbul, 1308/1890-1315/1897, vol. 1, pp. 184-5.

59. Ahmed, Risale fi İlmi Tulsım ve Def'i' 't-Taun, fols 85A, 87A-B, 98B.

60. Ahmed, Risale fi İlmi Tilsim ve Def'i' 't-Taun, fol. 81 B.

61. Jacques Gaffarel, Unheard-of Curiosities: Concerning the Talismanical Sculpture of the Persians; The Horoscope of the Patriarkes; and the Reading of the Stars. Written in French, by James Gaffarel. And Englished by Edmund Chilmead, Mr. of Arts, and Chaplaine of Christ-Church Oxon, pp. 150, 152-8.

62. T. Fahr, 'Huruf (Ilm al-)', Encyclopedia of Islam (online edition). 
63. Gaffarel, Unheard-of Curiosities, pp. 153-4.

64. Ahmed, Risale fi İlmi Tilsim ve Def'i' 't-Taun, fols 85B-86A.

65. Gaffarel, Unheard-of Curiosities, p. 165.

66. Mantran, Yüzyllın İkinci Yarısında İstanbul, pp. 233-6.

67. Mantran, Yüzyllın İkinci Yarısında İstanbul, p. 236.

68. Halil İnalcik, 'Bayazid II', and 'Istanbul', Encyclopedia of Islam.

69. Pamela H. Smith, The Business of Alchemy: Science and Culture in the Holy Roman Empire, pp. 5-13.

70. Kemp, A Brief Treatise, p. i.

71. Smith, The Business of Alchemy, pp. 209-17.

72. Gaffarel, Unheard-of Curiosities, pp. 166-7.

73. Gaffarel, Unheard-of Curiosities, pp. 18-20.

74. Yates, Occult Philosophy, pp. 37-46, 63-9, 116-19; Frances Yates, Giordano Bruno and the Hermetic Tradition, pp. 130-43.

75. Gadbury, London's Deliverance, pp. i, 24, 31; William Lilly, England's Propheticall Merline, foretelling to all Nations of Europe untill 1663. The Actions depending upon the Influence of the Conjunction of Saturn and Jupiter, 1642/3. The Progresse and Motion of the Comet 1618. Under Whole Effects we in England, and Most Regions of Europe now suffer. What Kingdomes must yet partake of the Remainder of the Influence, viz. of War, Plague, Famine, etc. When the English Common-wealth may expect Peace, and the City of London Better Times. The Beginning, and End of the Watry Trygon: An Entrance of the Fiery Triplicity, 1603. The Nativities of some English Kings, and some Horary Question inserted: performed by William Lilly, Student in Astrologie, p. 26.

76. Bernard Capp, English Almanacs, 1500-1800: Astrology and the Popular Press, pp. 23-5.

77. Lilly, England's Propheticall Merline, pp. 60-1.

78. Gadbury, London's Deliverance, pp. 12-17, 39-40.

79. Henry Oldenburg, The Correspondence of Henry Oldenburg, vol. 2, pp. 523, 526-7.

80. Graunt, Natural and Political Observations, p. 24.

81. John Gadbury, Vox Solis: or, an Astrological Discourse of the Great Eclipse of the Sun, which happened on June 22. 1666: in 10 Deg. of the Watry Signe Cancer. Shewing what Effects may most probably attend it, and unto what Persons, Kingdoms and Countries, they are chiefly directed, pp. 25-7.

82. Gadbury, London's Deliverance, pp. 25-7.

83. Christopher Barker, England and Wales Sovereign by the Queene: A Proclamation against the Bringing in of Wines from Bordeaux in Respect to Plague being there.

84. Yates, Occult Philosophy, pp. 84-5; Yates, Giordano Bruno, pp. 1-156, 275-90.

85. Capp, English Almanacs, pp. 27, 29, 41-5.

86. Gadbury, London's Deliverance, p. 27.

87. Dols, The Black Death in the Middle East, pp. 281-302. 